\title{
PEMBELAJARAN TEMATIK TERPADU BERBASIS PENGEMBANGAN BERPIKIR KRITIS DAN BERPIKIR KREATIF PADA SISWA KELAS V SEKOLAH DASAR
}

\author{
Sariaman $^{1}$, Tahmid Sabri ${ }^{2}$, Amalia Sapriati ${ }^{3}$ \\ 1,2,3 Universitas Terbuka
}

\begin{abstract}
The purpose of this study is to describe the implementation of integrated thematic learning based on the development of critical thinking and creative thinking, to analyze student learning outcomes and evaluate the relationship between the implementation of integrated thematic learning, critical thinking activities and creative thinking activities on student learning outcomes. The research approach is a mixed methods approach. The data collection instrument consisted of observation sheets on the implementation of integrated thematic learning, students' critical thinking and creative thinking activities, tests, interview guidelines and documentation studies. The results showed that the teacher's ability in implementing integrated thematic learning scored 59 with the criteria of "Good Enough", students' critical thinking activities scored 62 with the criteria of "Good", creative thinking activities scored 60 with the criteria of "Enough", the results of the written test obtained the average value is 66 with the criteria "Enough" and the evaluation results show that there is a significant relationship between the ability of teachers to implement integrated thematic learning, critical thinking activities, creative thinking activities on student learning outcomes.
\end{abstract}

Keyword: Integrated Thematic, Critical Thinking, and Creative Thinking

\begin{abstract}
Abstrak: Tujuan penelitian ini adalah untuk menggambarkan pelaksanaan pembelajaran tematik terpadu berdasarkan pengembangan pemikiran kritis dan pemikiran kreatif, untuk menganalisis hasil belajar siswa dan mengevaluasi hubungan antara pelaksanaan pembelajaran tematik terpadu, kegiatan berpikir kritis dan kegiatan berpikir kreatif pada hasil belajar siswa. Pendekatan penelitian adalah pendekatan metode campuran. Instrumen pengumpulan data terdiri dari lembar pengamatan pelaksanaan pembelajaran tematik terpadu, kegiatan berpikir kritis dan berpikir kreatif siswa, tes, pedoman wawancara dan studi dokumentasi. Hasil penelitian menunjukkan bahwa kemampuan guru dalam melaksanakan pembelajaran tematik terpadu memperoleh nilai 59 dengan kriteria "Cukup Baik", kegiatan berpikir kritis siswa memperoleh skor 62 dengan kriteria "Baik", kegiatan berpikir kreatif memperoleh nilai 60 dengan kriteria "Cukup", hasil tes tertulis memperoleh nilai rata-rata 66 dengan kriteria "Cukup" dan hasil evaluasi menunjukkan bahwa terdapat hubungan yang signifikan antara kemampuan guru dalam melaksanakan pembelajaran tematik terpadu, kegiatan berpikir kritis, kegiatan berpikir kreatif pada hasil belajar siswa. Kata Kunci: Tematik Terpadu, Berpikir Kritis, dan Berpikir Kreatif.
\end{abstract}

\footnotetext{
' Universitas Terbuka, Email: fluqman29回gmail.com

${ }^{2}$ Universitas Tanjungpura, Email: tahmid pgsd国yahou.co.id

${ }^{3}$ Universitas Terbuka, Email: lia国ecampus.ut.ac.id
} 


\section{PENDAHULUAN}

Memasuki abad ke-21 dunia mengalami perubahan yang sangat cepat. Perubahan terjadi di semua lini kehidupan termasuk bidang pendidikan. US-based Partnership for 21st Century Skills (P21) mengidentifikasi kompetensi yang diperlukan di abad ke-21 yaitu critical thinking, communiaction, collaboration, creativity. Revolusi pendidikan di Indonesia salah satunya dilakukan dengan pergantian kurikulum. Penerapan kurikulum 2013 edisi revisi berlandaskan pada Permendikbud Nomor 21 Tahun 2016. Perubahan mendasar pada kurikulum 2013 di jenjang sekolah dasar (SD) terletak pada penerapan model pembelajaran tematik terpadu pada semua tingkatan (kelas I sampai kelas VI). Pembelajaran tematik terpadu merupakan suatu jawaban mengenai tantangan akan masa depan Indonesia karena model pembelajaran ini menekankan pada proses belajar yang memberikan siswa suatu pengalaman yang berkaitan dengan keahlian tertentu yang dimiliki siswa. Keahlian tersebut meliputi kemampuan berkomunikasi, kerja sama, berpikir kritis dan berpikir kreatif.

Kenyataan di lapangan, belum semua aspek 4C sudah diterapkan dalam proses pembelajaran. Berdasarkan hasil observasi terhadap lima sekolah di Kecamatan Sayan, pada pertanyaan tentang apakah pembelajaran di kelas sudah menumbuhkan keterampilan berkomunikasi $80 \%$ guru menjawab sudah, pada pertanyaan apakah pembelajaran di kelas sudah menumbuhkan kemampuan kerja sama $60 \%$ guru menjawab sudah, pada pertanyaan apakah pembelajaran di kelas sudah menumbuhkan kemampuan berpikir kritis $40 \%$ guru menjawab sudah dan ketika ditanya apakah pembelajaran di kelas sudah menumbuhkan kemampuan berpikir kreatif hanya $20 \%$ guru menjawab sudah.

Haryadi, dkk. (2017, hlm. 2) dalam jurnal penelitian tentang pengaruh penerapan pembelajaran tematik terpadu terhadap kemampuan 4C siswa, menyimpulkan bahwa: pembelajaran tematik terpadu berpengaruh positif terhadap dua aspek keterampilan 4C yaitu kemampuan berkomunikasi (communication) dan kemampuan kerja sama (colaboration). Keterampilan tersebut terbentuk melalui pendekatan ilmiah (scientific) yang mereka lakukan selama proses pembelajaran. Melalui langkah-langkah ilmiah tersebut, siswa menjadi terbiasa untuk berkomunikasi (communication) dan kerja sama (colaboration). Aspek 4C yang lain yaitu critical thinking dan creative thinking masih belum memiliki pengaruh yang signifikan.

Berdasarkan hasil observasi, pendapat Haryadi, dkk. (2017) peneliti menyimpulkan bahwa: penerapan kurikulum 2013 dengan model pembelajaran tematik terpadu terbukti mampu meningkatkan kemampuan berkomunikasi (communication), kerja sama (colaboration), untuk kemampuan critical thinking dan creative thinking belum menunjukkan pengaruh yang signifikan. Sementara itu untuk hasil belajar siswa juga belum menunjukkan peningkatan. Hal ini bertentangan dengan pendapat As'ari (2016, hlm. 1) yang mengatakan bahwa tujuan penerapan pembelajaran tematik terpadu dengan pendekatan scientific approach adalah untuk mengembangkan sikap ilmiah dan menumbuhkan keterampilan belajar abad ke-21 yang mencakup semua aspek 4C yaitu critical thinking, communication. collaboration, creativity. Berdasarkan adanya kesenjangan antara harapan yang diinginkan dengan kenyataan yang terjadi, maka peneliti tertarik untuk melakukan penelitian di SD Kecamatan Sayan yang merupakan salah satu kecamatan yang berada di zona 3T tentang "Pembelajaran tematik terpadu berbasis pengembangan berpikir kritis dan berpikir kreatif pada siswa kelas V sekolah dasar".

\section{METODOLOGI PENELITIAN}

Penelitian ini merupakan penelitian mixed methods, yaitu suatu langkah 
penelitian yang menggabungkan dua bentuk pendekatan dalam penelitian, yaitu kuantitatif dan kualitatif. Penelitian ini dilakukan di SD Kecamatan Sayan, yaitu 1) SD Negeri 01 Sayan, 2) SD Negeri 06 Nanga Sasak, 3) SD Negeri 09 Nanga Sayan, 4) SD Negeri 14 Kayu Baong, 5) SD Negeri 16 Landau Siling. Sumber informasi dalam penelitian ini adalah siswa kelas $\mathrm{V}$ berjumlah 62 siswa, guru kelas V berjumlah 5 orang dan Kepala Sekolah sebanyak 5 orang. Instrumen pengumpulan data yang digunakan berupa Lembar Observasi IPKG 2, Lembar Observasi Aktivitas critical thinking, Lembar Aktivitas creative thinking, Soal Tes dan Pedoman Wawancara Kepala Sekolah serta Guru Kelas V. Teknik analis data yang digunakan merupakan kombinasi antara teknik kualitatif dan kuantitatif. Data berupa angka-angka dianalisis menggunakan teknik kuantitatif kemudian disajikan dalam bentuk kualitatif. Proses penyajian data kualitatif menggunakan model Miles dan Huberman (2014) yaitu pengumpulan data, penyajian data, reduksi data, dan penarikan kesimpulan/verifikasi data.

\section{HASIL PENELITIAN DAN PEMBAHASAN}

Bagian ini penulis mencoba untuk menyampaikan hasil penelitian yang dapat dijabarkan melalui tabel di bawah ini.

Tabel 1. Distribusi Frekuensi Aktivitas Critical Thinking Siswa

\begin{tabular}{|c|c|c|c|}
\hline No & Keterangan & Frekuensi & Persentase \\
\hline 1 & Baik & 35 & $56 \%$ \\
\hline 2 & Cukup & 27 & $44 \%$ \\
\hline
\end{tabular}

Berdasarkan tabel di atas, terlihat bahwa aktivitas yang mencerminkan kemampuan berpikir kritis pada siswa SD Kecamatan Sayan berada pada kriteria "Baik". Cahyono (2017, hlm. 56) mengatakan bahwa indikator berpikir kritis: Focus, Reason, Inference, Situation, Clarity, and Overview yang dapat disingkat dengan istilah FRISCO. Senada dengan pendapat di atas Zubaidah, dkk. (2018, hlm. 3) menjelaskan komponen FRISCO dalam proses pembelajaran sebagai berikut: $\mathrm{F}$ (Focus) yaitu memfokuskan pertanyaan atau isu yang ada untuk membuat keputusan tentang apa yang diyakini. $\mathrm{R}$ (Reason) untuk mengetahui alasan yang mendukung atau menolak putusan-putusan yang dibuat berdasar situasi dan fakta yang relevan. I (Inference) untuk membuat kesimpulan yang beralasan atau meyakinkan. Bagian penting dari langkah penyimpulan ini adalah mengidentifikasi asumsi dan mencari pemecahan, pertimbangan dari interpretasi terhadap situasi dan bukti. S (Situation) untuk memahami situasi dan selalu menjaga situasi dalam berpikir untuk membantu memperjelas pertanyaan (dalam F) dan mengetahui arti istilah-istilah kunci, bagian-bagian yang relevan sebagai pendukung. $\mathrm{C}$ (Clarity) untuk menjelaskan arti atau istilah-istilah yang digunakan. $\mathrm{O}$ (Overview) untuk meninjau kembali dan meneliti secara menyeluruh keputusan yang diambil.

Pada proses pembelajaran tematik terpadu, terlihat bahwa aspek aktivitas focus, sebanyak 22 siswa berada pada kriteria "Cukup" dan 40 siswa berada pada kriteria "Baik", pada saat pembelajaran siswa fokus pada langkah-langkah kegiatan yang disajikan guru, saat mengamati gambar yang ada di buku siswa terlihat sangat tertarik dan bersemangat ketika menyampaikan kepada guru. Aspek reason, 26 siswa berada pada kriteria "Cukup" dan 36 sisa berada pada kriteria "Baik", secara umum memperoleh nilai rata-rata dengan kriteria "Baik", dalam proses pembelajaran siswa sudah berani memberikan reaksi dengan menggali lebih dalam tentang gambar-gambar yang ada pada buku dan dibuktikan dengan mereka mulai berani bertanya kepada guru jika ada hal yang tidak jelas. Sementara itu, aspek inferen, 28 siswa berada pada kriteria "Cukup" dan 34 siswa berada pada kriteria "Baik", aktivitas menyimpulkan, menanya dan menyampaikan hasil temuan merupakan aspek yang paling banyak muncul dalam proses pembelajaran tematik terpadu. 
Dalam proses pembelajaran terlihat bahwa siswa terlibat aktif dalam bertanya, berdikusi dan menyampaikan pendapat.

Pada aspek situation, 29 siswa berada pada kriteria "Cukup" dan 33 siswa berada pada kriteria "Baik", kegiatan pembelajaran terjadi dalam langkahlangkah yang sudah sesuai dengan tahapan pembelajaran tematik terpadu, siswa menyesuaikan informasi yang mereka peroleh dengan situasi pembelajaran, contohnya saat waktu presentasi siswa melakukan persentasi dengan tertib sesuai undian yang didapat, begitu juga ketika bertanya siswa bertanya sesuai dengan topik yang dibahas baik oleh guru maupun oleh siswa yang lain. Pada aspek clarity terdapat 31 siswa dengan kriteria "Cukup" dan 31 siswa dengan kriteria "Baik". Sedangkan pada aspek aktivitas siswa menjelaskan istilah-istilah penting dari materi pembelajaran memperoleh nilai ratarata pengamatan dengan kriteria "Baik". Separuh siswa sudah mampu menjelaskan istilah-istilah yang ada dibuku. Siswa juga mampu memberikan argumen yang logis dan bisa diterima oleh rekan lain. Pada aspek yang terakhir dari aktivitas critical thinking pembelajaran tematik adalah aspek overview. Aspek ini terkait dengan kemampuan meneliti kembali apa yang ingin disampaikan, jawaban dan kesimpulan. Aspek overview memperoleh nilai rata-rata dengan kriteria "Cukup". Pada proses pembelajaran, siswa kurang mencerminkan aktivitas overview seperti melihat kembali dan memeriksa dengan teliti hasil pendapat, jawaban dan kesimpulan yang akan disampaikan.

Haryadi, dkk. (2017, hlm. 9) mengatakan bahwa salah satu amanat kurikulum 2013 melalui pembelajaran tematik terpadu mensyaratkan siswa harus dapat mengembangkan keterampilan berpikir kritis. Keterampilan berpikir kritis dapat diajarkan sejak mereka SD, tetapi harus mempertimbangkan tahap perkembangan anak. Salah satu caranya dengan menggunakan pembelajaran tematik yang diintegrasikan dengan keterampilan berpikir kritis. Keterampilan berpikir kritis tidak muncul dengan sendirinya tetapi harus dilatih secara terusmenerus. Latihan rutin yang dilakukan siswa berdampak pada efisiensi dan otomatisasi keterampilan berpikir yang dimiliki siswa. Jika siswa terbiasa dengan pola berpikir kritis, diharapkan mereka dapat menyaring informasi dan meningkatkan pembentukan karakter dalam menghadapi era global.

Hasil observasi terhadap aktivitas berpikir kritis pada saat pembelajaran tematik terpadu menunjukkan bahwa secara keseluruhan pelaksanaan pembelajaran tematik terpadu di SD Kecamatan Sayan belum sepenuhnya mengembangkan kemampuan berpikir kritis. Hal ini sesuai dengan hasil penelitian Sani (2019, hlm. 54) bahwa pembelajaran tematik terpadu salah satu manfaatnya adalah mengembangkan keterampilan berpikir kritis pada siswa.

Tabel 2. Distribusi Frekuensi Aktivitas Creative Thinking Siswa

\begin{tabular}{|c|c|c|c|}
\hline No & Keterangan & Frekuensi & Persentase \\
\hline 1 & Baik & 33 & $53 \%$ \\
\hline 2 & Cukup & 29 & $47 \%$ \\
\hline
\end{tabular}

Zubaidah, dkk. (2018, hlm. 7) mengatakan bahwa kemampuan berpikir kreatif merupakan keterampilan penting bagi siswa karena memiliki hubungan langsung dengan pengembangan konten pengetahuan dan keterampilan. Berpikir kreatif sebagai kemampuan untuk merumuskan masalah, membuat dugaan, menghasilkan ide-ide baru, dan mengomunikasikan hasil-hasil.

Berdasarkan hasil observasi terhadap aktivitas pembelajaran tematik terpadu di peroleh skor aktivitas kemampuan kreatif siswa dengan rincian sebagai berikut: aktivitas yang mencerminkan kemampuan creative thinking pada siswa kelas V SD di Kecamatan Sayan sebanyak 53\% siswa berada pada kriteria "Baik" sedangkan 47\% siswa masih berada pada kriteria "Cukup". Yuliani (2017, hlm. 52) mengatakan bahwa 
indikator kemampuan berpikir kreatif (creative thinking) berupa kefasihan (fluency), fleksibilitas (fleksibility) dan kebaruan (originality). Adapun rincian sebaran kemampuan kreatif siswa berdasarkan empat aspek tersebut sebagai berikut.

$$
\text { Aspek kelancaran (fluency) }
$$

merupakan kemampuan mencetuskan banyak gagasan, jawaban, penyelesaian suatu masalah, atau pertanyaan yang diajukan dengan mudah. Berdasarkan hasil observasi, aktivitas kelancaran mendapatkan skor dengan kriteria "Cukup". Terlihat dalam proses pembelajaran siswa mulai bisa memberikan jawaban, pendapat dan saran dengan menggunakan bahasa yang mudah dipahami. Selain itu, siswa juga sudah berani mengajukan pertanyaan dan menyampaikan pendapat baik kepada guru maupun kepada sesama siswa. Hasil tersebut sesuai dengan pendapat Gunawan, dkk. (2016, hlm. 5) mengatakan bahwa jika seorang anak yang lancar berpikir kreatif diberi suatu pertanyaan dia akan cenderung memberikan beberapa alternatif jawaban. Ciri-ciri anak yang lancar berpikir kreatif adalah banyak bertanya, memiliki banyak alternatif jawaban, memiliki banyak gagasan/ide dalam menyikapi sesuatu, dalam berinteraksi anak akan bekerja lebih banyak dan melakukan lebih banyak hal dibandingkan dengan teman-temannya. Anak yang lancar berpikir kreatif juga cenderung dapat mengidentifikasi kesalahan atau kekurangan pada suatu obyek dengan cepat.

Fleksibel (Flexibility) dalam berpikir kreatif merupakan kemampuan menghasilkan banyak alternatif gagasan, pertanyaan dan jawaban yang bervariasi, kemampuan melihat sesuatu dari sudut pandang yang berbeda, kemampuan mencari banyak alternatif/arah yang berbeda. Fleksibel dalam berpikir kreatif memungkinkan seseorang mampu mengubah pendekatan atau cara pemikiran dengan mudah. Ciri-ciri anak yang berpikir kreatif secara fleksibel adalah mampu menunjukkan aneka ragam penggunaan yang tidak lazim dari suatu obyek, mampu memberi berbagai macam penafsiran (interpretasi) terhadap sesuatu gambar, cerita, dan masalah, mampu menerapkan suatu konsep atau asas dengan cara yang berbeda-beda. Anak yang fleksibel dalam berpikir kreatif juga akan cenderung memiliki posisi yang berbeda atau bahkan bertentangan dengan mayoritas kelompoknya ketika melakukan diskusi atau membahas suatu masalah bersamasama. Anak yang fleksibel dalam berpikir kreatif cenderung menggolongkan hal-hal menurut pembagian atau kategori yang berbeda dan mampu mengubah arah pemikiran secara spontan. Dalam proses pembelajaran, aktivitas tersebut sudah tergambarkan dalam berbagai aktivitas siswa sehingga memperoleh skor dengan kriteri "Baik".

Orisinal (originality) dalam berpikir kreatif merupakan kemampuan melahirkan ungkapan baru yang unik, kemampuan memikirkan cara yang tidak lazim untuk mengungkapkan diri sendiri, dan kemampuan membuat kombinasikombinasi yang tidak lazim dari bagianbagian atau unsur-unsur. Ciri-ciri anak yang berpikir kreatif secara orisinal adalah selalu memikirkan masalah-masalah atau hal-hal yang tidak pernah terpikirkan oleh orang lain, selalu mempertentangkan caracara yang lama dan berusaha memikirkan cara-cara yang baru. Anak yang orisinal dalam berpikir kreatif cenderung memilih sesuatu yang asimetri dalam membuat gambar dan desain suatu obyek, selalu mencari pendekatan yang baru dari yang stereotip, dan lebih menyenangi sesuatu yang bersifat sintesis daripada sekedar menganalisis. Anak yang orisinalitas dalam berpikir kreatif akan bekerja untuk menemukan permasalahan yang baru setelah membaca atau mendengar gagasan. Unsur-unsur kemampuan berpikir kreatif aspek orisinil merupakan aspek terlemah sehingga skor yang diperoleh berdasarkan hasil observasi berada pada kriteria "Cukup". 
Kerincian (elaboration) merupakan kemampuan memperkaya atau mengembangkan suatu gagasan yang dimiliki oleh diri sendiri maupun orang lain. Siswa yang dapat berpikir kreatif secara rinci akan mampu menambahkan detail-detail tertentu dari suatu obyek, gagasan, dan situasi sehingga lebih menarik. Ciri-ciri anak yang dapat berpikir kreatif secara rinci adalah selalu mencari arti yang lebih dalam terhadap jawaban pertanyaan yang diajukan, melakukan pemecahan masalah dengan cara yang terperinci, mampu mengembangkan atau memperkaya gagasan orang lain, selalu mau mencoba atau menguji detail-detail suatu obyek untuk melihat arah-arah yang akan ditempuh, dan memiliki rasa keindahan yang kuat sehingga tidak puas dengan penampilan kosong atau sederhana. Ciri-ciri siswa yang mampu berpikir kreatif berdasarkan aspek kerincian belum begitu nampak pada aktivitas pembelajaran sehingga mendapat skor dengan kriteria "Cukup".

Berdasarkan hasil observasi terhadap aspek kemampuan berpikir kreatif pada siswa kelas V SD Kecamatan Sayan, peneliti menyimpulkan bahwa aktivitas siswa yang menunjukkan kemampuan berpikir kreatif belum tergambar dengan baik dalam proses pembelajaran, dari empat aspek yang diamati hanya satu aspek yang memperoleh skor dengan kriteria "Baik", sementara tiga aspek lainnya hanya memperoleh kriteria "Cukup".



Berdasarkana gambar I di atas kemampuan berpikir kritis siswa kelas V SD Kecamatan Sayan dengan rincian sebagai berikut: dari 62 siswa yang mengikuti tes tertulis, sebanyak 34 siswa memperoleh nilai antara interval 55-69 dengan sebuta kriteria "Cukup", sedangkan 28 siswa memperoleh nilai dalam interval 70-84 dengan kriteria "Baik". Selanjutnya jika di analasis lebih mendalam ternyata hanya 45\% siswa kelas V SD di Kecamatan Sayan yang memiliki kemampuan berpikir kritis dengan kriteria "Baik", sedangkan sebanyak 55\% siswa masih berada pada kriteria kemampuan berpikir kritis "Cukup". Husnah (2017, hlm. 7) menyimpulkan bahwa kemampuan berpikir kritis pada siswa paling ideal adalah pada rentang kriteria Baik. Berdasarkan tes hasil belajar tersebut dapat disimpulkan bahwa kemampuan berpikir kritis pada siswa kelas V SD Kecamatan Sayan masih rendah karena belum berada pada kriteria "Baik".

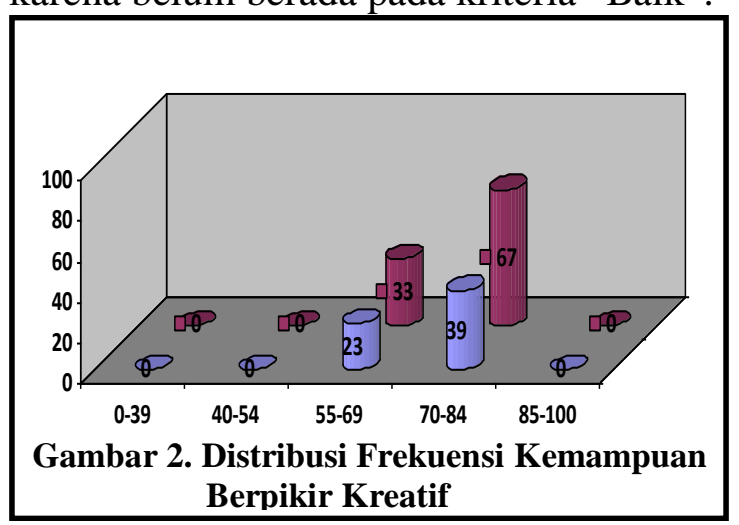

Menurut Moma (2016, hlm. 31) pertanyaan yang mampu menstimulus kemampuan berpikir kreatif adalah pertanyaan yang mengarahkan siswa untuk membuat suatu keputusan yang didasarkan pada ide individu ataupun pada pengalaman individu. Siswa harus menganalisis situasi kemudian membuat keputusan. Dalam penelitian ini, soal yang digunakan selalu di awali dengan kalimat pembuka atau kalimat pengantar kemudian baru diajukan pertanyaan.

Berdasarkan hasil analisis data didapat kemampuan berpikir kreatif siswa kelas V SD Kecamatan Sayan dengan rincian: dari 62 siswa yang mengikuti tes tertulis, sebanyak 39 siswa memperoleh nilai antara interval 55-69 dengan sebutan kriteria "Cukup", sedangkan 23 siswa memperoleh nilai dalam interval 70-84 
dengan kriteria "Baik". Selanjutnya, jika dianalasis lebih mendalam, ternyata hanya $33 \%$ siswa kelas V SD di Kecamatan Sayan yang memiliki kemampuan berpikir kreatif dengan kriteria "Baik", sedangkan sebanyak $67 \%$ siswa masih berada pada kriteria kemampuan berpikir kreatif "Cukup". Berdasarkan hasil tersebut, apabila dihubungkan dengan perolehan skor kemampuan siswa berdasarkan hasil tes, dapat disimpulkan kemampuan siswa kelas V SD Kecamatan Sayan berada pada kriteria "Cukup Kreatif".

Widana (2017, hlm. 3-4) mengatakan bahwa salah satu keunggulan soal High Order Thinking adalah kemampuan dalam mengukur keterampilan bepikir kritis (critical thinking) dan keterampilan berpikir kreatif (creative thinking). Adapun Ikhsan dkk. (2019, hlm. 9-10) mengatakan bahwa kemampuan berpikir kritis dan kreatif merupakan dua hal yang saling keterkaitan sehingga dalam mengukur kemampuan tersebut dapat menggunakan soal tes jenis High Order Thinking (HOTS). Beradasarkan pendapat tersebut, kemampuan berpikir kritis maupun kemampuan berpikir kreatif pada peelitian ini tidak diukur mengunakan soal tes secara khusus dan terpisah. Peneliti menggabungkan kedua tingkat berpikir kritis dan kreatif ini karena saling berhubungan antara satu dan yang lain. Kriteria Ketuntasan Minimal yang digunakan yaitu 70 dengan interval 0-69 (D), 70-79 (C), 80-89 (B) dan 90-100 (A). Deskripsi hasil belajar siswa setelah mengikuti pembelajaran tematik terpadu berbasis pengembangan kemampuan critical thinking dan creative thinking sebagai berikut:

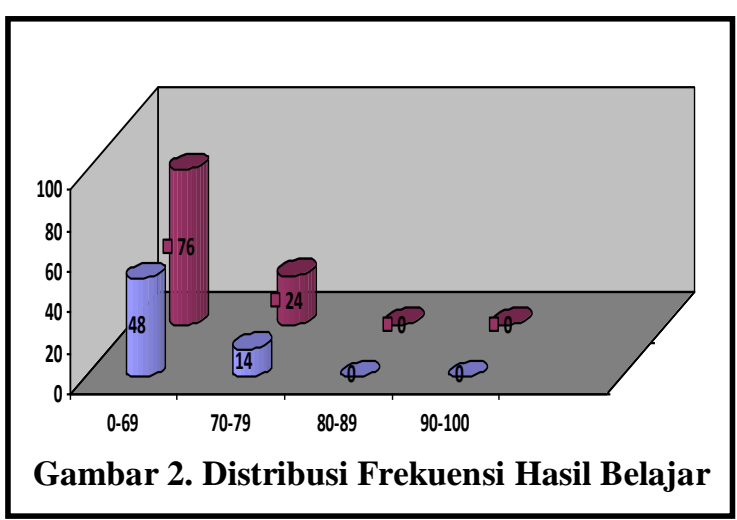

Rofiah (2013, hlm. 12-15) dalam jurnalnya mengatakan bahwa salah indikator siswa sudah memiliki kemampuan berpikir kritis dan kreatif adalah mampu mengerjakan soal High Order Thinking (HOTS) dengan kriteria baik. Hasil tes ini mencerminkan bahwa sebenarnya siswa belum terbiasa mengerjakan soal yang berhubungan dengan kegiatan berpikir terutama dalam hal menganalisis, mengkreasi ide dan menyimpulkan.

Setelah mengamati kemampuan guru dalam mengimplementasikan pembelajaran tematik terpadu, aktivitas berikir kritis dan aktivitas berpikir kreatif serta memperoleh hasil belajar siswa melalui soal tes. Tahap terakhir dalam penelitian ini ialah mencari keterhubungan antara kemampuan guru dalam implementasi pembelajaran tematik terpadu, aktivitas critical thinking, aktivitas creative thinking dengan hasil belajar siswa. Untuk mencari keterhubungan tersebut, menggunakan SPSS 24. Berdasarkan hasil pengolahan data dapat disimpulkan bahwa secara simultan kemampuan guru dalam implementasi pembelajaran tematik terpadu, aktivitas critical thinking, aktivitas creative thinking memiliki keterhubungan signifikan dengan hasil belajar siswa. Dari persamaan regresi, diketahui bahwa nilai konstanta sebesar 19,555. Angka tersebut menunjukkan bahwa apabila variabel kemampuan guru mengimplementasikan tematik terpadu, aktivitas berpikir kritis siswa dan aktivitas berpikir kreatif siswa jika nilainya 0 hasil belajar siswa memiliki tingkat kinerja sebesar -19,555. Nilai koefisien 
kemampuan guru mengimplementasikan pembelajaran tematik terpadu sebesar 0,959 dengan nilai positif. Hal ini berarti bahwa setiap peningkatan koefisien kemampuan guru mengimplementasikan pembelajaran tematik terpadu sebesar $1 \mathrm{kali}$ maka hasil belajar siswa akan meningkat sebesar 0,959 dengan asumsi variabel yang lain konstan. Nilai koefisien aktivitas berpikir kritis siswa dalam pembelajaran tematik sebesar 0,393 dengan nilai positif. Hal ini berarti bahwa setiap peningkatan koefisien aktivitas berpikir kritis siswa dalam pembelajaran tematik sebesar $1 \mathrm{kali}$ maka hasil belajar siswa akan meningkat sebesar 0,393 dengan asumsi variabel yang lain konstan. Nilai koefisien aktivitas berpikir kreatif siswa dalam pembelajaran tematik sebesar 0,076 dengan nilai positif. Hal ini berarti bahwa setiap peningkatan koefisien aktivitas berpikir kreatif siswa dalam pembelajaran tematik sebesar 1 kali maka hasil belajar siswa akan meningkat sebesar 0,076 dengan asumsi variabel yang lain konstan.

Berdasarkan hasil uji $\mathrm{t}$ diketahui bahwa variabel kemampuan guru mengimplementasikan pembelajaran tematik terpadu mempunyai nilai t hitung 24,982 lebih besar dari t-tabel 2,015 dan diperoleh nilai signifikansi 0,035 lebih kecil dari taraf signifikansi $0,05(0,025<0,05)$. Dengan demikian, dapat disimpulkan bahwa variabel kemampuan guru mengimplementasikan pembelajaran tematik terpadu memiliki keterhubungan yang signifikan dengan hasil belajar siswa. Variabel aktivitas berpikir kritis siswa dalam pembelajaran tematik terpadu mempunyai nilai thitung 17,955 lebih besar dari t-tabel 2,015 dan diperoleh nilai signifikansi 0,025 lebih kecil dari taraf signifikansi $0,05(0,035<0,05)$. Dapat disimpulkan bahwa variabel aktivitas berpikir kritis siswa dalam pembelajaran tematik terpadu memiliki keterhubungan yang signifikan dengan hasil belajar siswa. Variabel aktivitas berpikir kreatif siswa dalam pembelajaran tematik terpadu mempunyai nilai t-hitung 1,847 lebih kecil dari t-tabel 2,015 dan diperoleh nilai signifikansi 0,316 lebih besar dari taraf signifikansi $0,05(0,316>0,05)$. Dengan demikian, dapat disimpulkan bahwa variabel aktivitas berpikir kreatif siswa dalam pembelajaran tematik terpadu tidak mmemiliki keterhubungan yang signifikan dengan hasil belajar siswa.

Sementara itu, variabel independen yang paling erat keterhubungannya dengan hasil belajar siswa yakni variabel kemampuan guru dalam mengimplementasikan pembelajaran tematik terpadu dengan nilai Standardized Coefficients Beta 1,032. Sementara itu, variabel independen yang tingkat keterhubungannya lemah dengan hasil belajar siswa adalah aktivitas creative thinking siswa dalam pembelajaran tematik terpadu.

Dari hasil uji koefisien determinasi, diperoleh nilai adjusted $R$ Square sebesar 0,995 atau $99,5 \%$. Hal ini menunjukkan bahwa hasil belajar siswa dijelaskan sebesar $99,5 \%$ oleh variabel independen yaitu kemampuan guru dalam mengimplementasikan pembelajaran tematik terpadu, aktivitas berpikir kritis siswa dan aktivitas berpikir kreatif siswa. Sedangkan $0,50 \%$ variasi hasil belajar dijelaskan oleh variabel di luar variabel independen penelitian ini.

Adanya hubungan yang signifikan antara kemampuan guru dalam implementasi pembelajaran tematik terpadu, aktivitas critical thinking, aktivitas creative thinking dengan hasil belajar siswa sesuai dengan peneilitian yang dilakukan oleh Gunawan, dkk. (2016, hlm. 37) menyimpulkan bahwa terdapat hubungan yang signifikan antara kemampuan guru dalam mengimplementasikan pembelajaran tematik terpadu, aktivitas critical thinking, aktivitas creative thinking dengan hasil belajar siswa. Hasil penelitian ini juga sesuai dengan teori awal penerapan kurikulum 2013 yaitu untuk meningkatkan keterampilan 4C pada siswa terutama pada kemampuan berpikir kritis, berpikir kreatif serta memiliki keterampilan berpikir 
tingkat tinggi dengan mampu mengerjakan soal jenis high order thinking (HOTS) dengan kriteria baik. Hasil penelitian ini membuktikan bahwa kemampuan guru dalam mengimplementasikan pembelajaran tematik terpadu memiliki hubungan yang paling kuat dengan hasil belajar siswa, artinya semakin baik guru dalam mengimplementasikan pembelajaran tematik terpadu maka hasil belajar siswa akan juga akan meningkat.

\section{KESIMPULAN}

Berdasarkan temuan penelitian dan pembahasan, di dalam penelitian ini trdapat beberapa simpul. Pelaksanaan pembelajaran tematik terpadu pada siswa SD kelas V di Kecamatan Sayan telah memenuhi kriteria cukup baik. Hal ini ditunjukkan dengan hasil observasi pelaksanaan pembelajaran tematik terpadu yang mendapatkan kriteria "Cukup". Pembelajaran tematik terpadu yang diterapkan pada siswa kelas $\mathrm{V}$ SD Kecamatan Sayan sudah mencerminkan pengembangan kemampuan berpikir kritis (critical thinking) dan berpikir kreatif (creative thinking). Hal ini dibuktikan dengan hasil pengamatan sebanyak $52 \%$ siswa kelas $\mathrm{V}$ sudah menunjukkan adanya aktivitas berpikir kritis dengan kriteria "Baik" dan $48 \%$ siswa kelas V menunjukkan aktivitas berpikir kritis dengan kriteria "Cukup". Adapun kemampuan bepikir kreatif (cretive thinking) sebanyak $53 \%$ siswa berada pada kriteria "Baik" dan 47\% siswa berada pada kriteria "Cukup". Hasil tes tertulis menggunakan soal High Order Thinking (HOTS) dari 62 siswa mengikuti tes sebanyak 28 siswa berada pada kriteria kemampuan "Baik", dan 34 siswa berada pada kriteria "Cukup". Terdapat keterhubungan yang signifikan antara kemampuan guru dalam implementasi pembelajaran tematik terpadu, aktivitas berpikir kritis dan aktivitas berpikir kreatif dengan hasil belajar siswa.

\section{DAFTAR PUSTAKA}

As'ari, A. R., Mahmudi, A., \& Nuerlaelah, E. (2017). Our Prospective Mathematic Teachers Are Not Critical Thinkers Yet. Journal on Mathematics Education, 8(2), 145156.

Cahyono, B. (2017). Analisis Ketrampilan Berfikir Kritis dalam Memecahkan Masalah Ditinjau Perbedaan Gender. Aksioma: Jurnal Matematika dan Pendidikan Matematika, 8 (1), 50-64.

Gunawan, I., Suraya, S. N., \& Tryanasari, D. (2016). Hubungan Kemampuan Berpikir Kreatif dan Kritis dengan Prestasi Belajar Mahasiswa pada Matakuliah Konsep Sains II Prodi PGSD IKIP PGRI MADIUN. Premiere Educandum: Jurnal Pendidikan Dasar dan Pembelajaran, 4(01).

Haryadi, S., Djatmika, E. T., \& Setyosari, P. (2017). Pembelajaran Tematik dalam Menumbuhkan Sikap Ilmiah dan Keterampilan Berpikir Kritis Siswa SD. In Prosiding Seminar Nasional Mahasiswa Kerjasama Direktorat Jenderal Guru dan Tenaga Kependidikan Kemendikbud 2016.

Husnah, M. (2017). Hubungan tingkat berpikir kritis terhadap hasil belajar fisika siswa dengan menerapkan model pembelajaran problem based learning. PASCAL (Journal of Physics and Science Learning), 1(2), 10-17.

Ikhsan, A. \& Auliya, A. (2019). High Order Thinking skill (HOTS) Analisis Kemampuan Siswa Menyelesaikan Soal Ujian Nasional HOTS Mata Pelajran Fisika SMA 10 Kota Bengkulu. Gravitasi: Jurnal Pendidikan Fisika dan Sains, 2 (02), 34-41.

Miles, H., \& Huberman, A. M. Saldana.(2014). Qualitative data analysis: A methods sourcebook, 3. 
Moma, L. (2016). Pengembangan Instrumen Kemampuan Berpikir Kreatif Matematis Untuk Siswa SMP. Delta-Pi: Jurnal Matematika dan Pendidikan Matematika, 4(1).

Rofiah, E., Aminah, N. S., \& Ekawati, E. Y. (2013). Penyusunan Instrumen Tes Kemampuan Berpikir Tingkat Tinggi Fisika pada Siswa SMP. Jurnal Pendidikan Fisika, 1(2).

Sani, R. A. (2019). Pembelajaran berbasis HOTS (Higher Order Thinking Skills). Tangerang: Tsmart.

Widana, I. W. (2017). Modul penyusunan soal higher order thinking skill (HOTS).

Yuliani, H., Mariati, M., Yulianti, R., \& Herianto, C. (2017). Keterampilan Berpikir Kreatif pada Siswa Sekolah Menengah di Palangka Raya Menggunakan Pendekatan Saintifik. Jurnal Pendidikan Fisika dan Keilmuan (JPFK), 3(1), 48-56.

Zubaidah, S. (2016, December). Keterampilan abad ke-21: Keterampilan yang diajarkan Melalui Pembelajaran. In Seminar Nasional Pendidikan dengan tema "Isu-isu Strategis Pembelajaran MIPA Abad (Vol. 21, No. 10). 